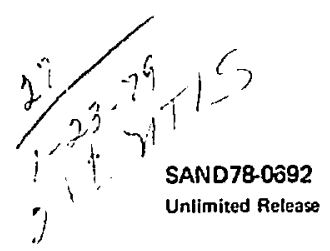

\title{
An Analog Subsystem for the Plutonium Protection System
}

H. Duane Arlowe

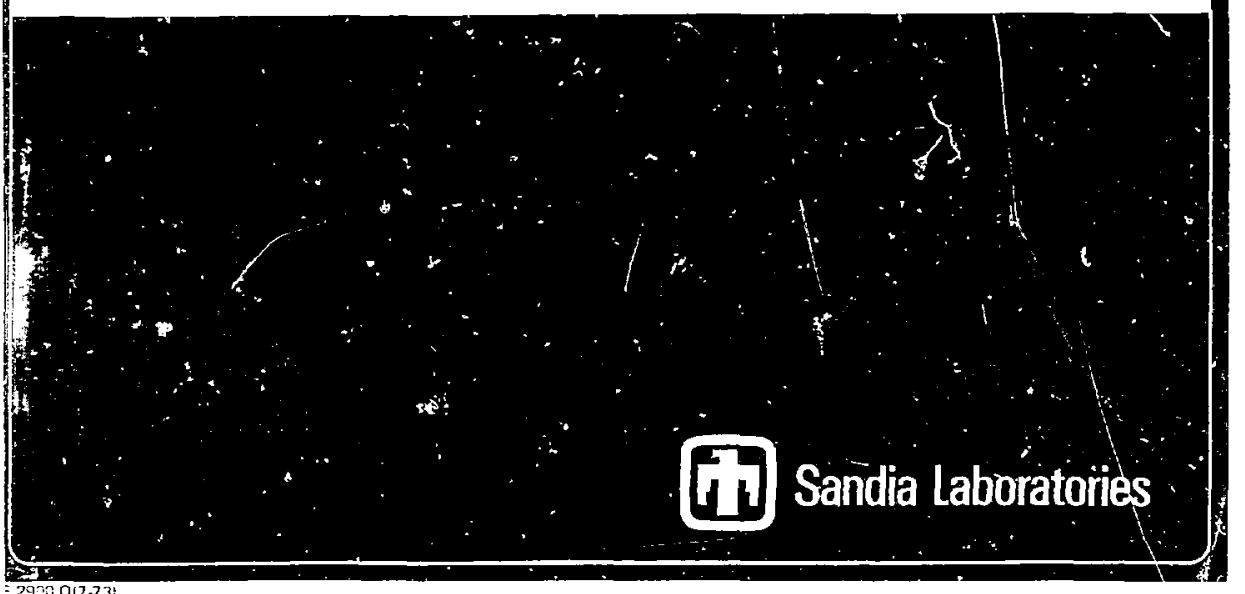

\section{MASTER}


(i) $31173-06 \%$

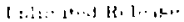

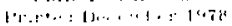

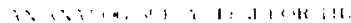

$[0,1 \therefore, \therefore ! 13+1]+1 !+1, \therefore, 1$.

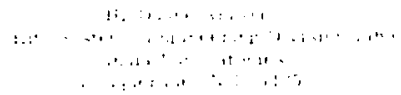

$\because \because \cdots, i t \cdot, 1$
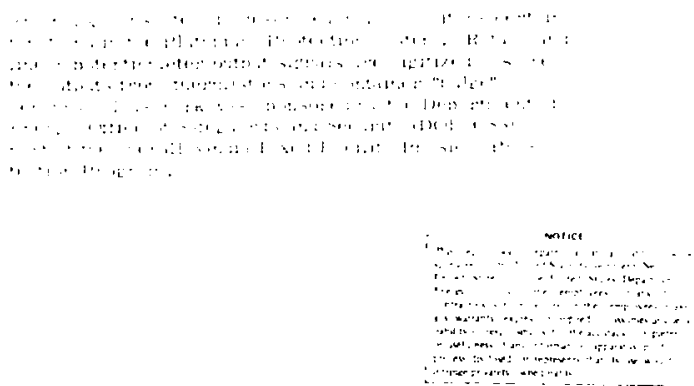


\section{CONTENTS}

Int roduction

Summary

System Degcription

Troubleshooting

Heplaceable Parta

References

APLENDIX A $\cdots$ Schematic Diagrams

APPliNUIX $B$ - Conversion Tables

\section{ILLLSTRITINS}

\begin{tabular}{|c|c|c|}
\hline 1 & Plutonium I'rotection System Organization & 8 \\
\hline 2 & Plutonium Protection System/Systems Intemeation Laboratory & 3 \\
\hline 3 & S.MI Analog Sulbsystem & 11 \\
\hline 4 & Vault Port and C.Ul' Room Controller & $n$ \\
\hline 5 & Variable Resistance Sensars & 12 \\
\hline 6 & Location and (1rientation of l' $^{2} \mathrm{C}$ cards & 15 \\
\hline
\end{tabular}


AN ANA LOG SUBSYSTEN FOR THE

PLUTONIUM PROTECTION SYSTEM

Introduction

The Plutonium Protection System (PPS) is an item protection system that demonstrates advanced storage concepts which integrate detection and delay elements with careful monitoring and control of operationa! procedures, In addition, the accountability, operations. and sccurity centers are physically separated to reduce vulnerability to insider threat. Organizition of the PPS is illustrated in Figure 1. The five components of the PPS are interconnected $w$ itis a data communications network:

- The Storage Vault is an Item Control Area (ICA) in which advanced detection ard delay elements reduce the vulnerability to insider and to forced entry tireats. Personnel access is carefully controlled and the threa contral centers continually interact to assure the proper movement of material.

- The Container Mortule Packaging (C.MP) room is an ICA which provides point of entry to the 1'l'S. i.e., material is packaged into standardized containers to prepare it for storage. For this demonstration, the CMF coom is under the direct control of the Mlaterial Operations Center; in actual applicalion. its structure would be similar to that of the vault, with access control and inturaction among three control centers.

- The Material ()perations Center (NCIC) is a control center which monitors and controls all operations involving mavement of items in the system.

- The Uaterial Accountability Center (MACl is a control center which maintains the arcountability of all items in the system.

- The Security operations Center (SOC) is a control center which monitors and responds to all alarms in the system and controls personnel access to the system.

Wovement of material between the ICAs is accomplished in a secure fushion liy means of a Secure Transport Module (STMI) which is essentially a minivault on wheels. The STM must be securely docked at a port in the all of the ICA before materia! can be loaded or unloaded. The actual transport ot material is caiefully timed to minimize the time available for tampering or diversion. 


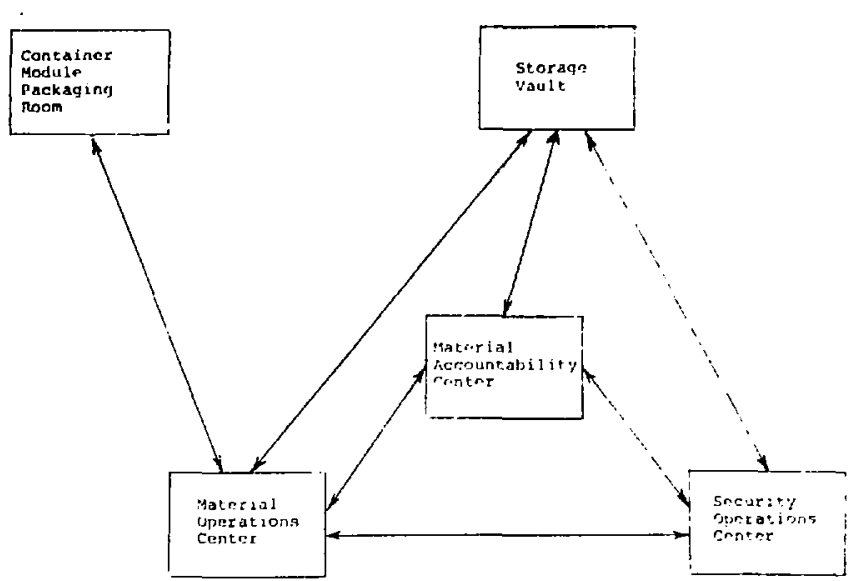

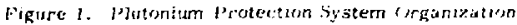

The focal point of the pris is the valt, which moludes a personnel entev crorrudur, alarm and assessment comporients, a protected computer, and a storage room that contalis lecurt

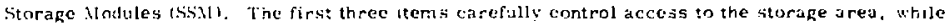

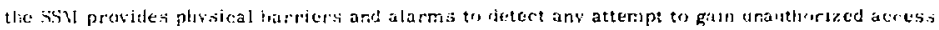

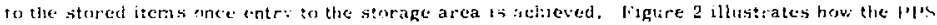

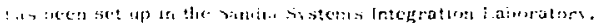

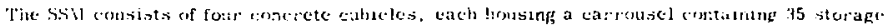
locauons $\mathrm{l}$ s seven lavers of five posituons each, The storaje locations are staggered so thut the

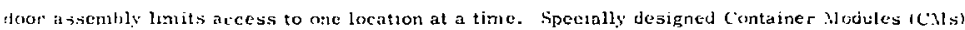

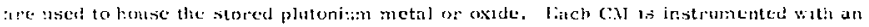

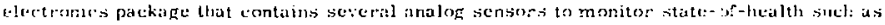

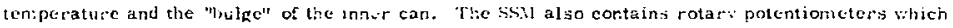
monitor the position of the carrousels. These analog signals must be digutued to be computible xith: the microprocessor-based SSY contr-ller.

The Analog Sitssysten discussed in lus repost accomplishes the signal conditioning requirce

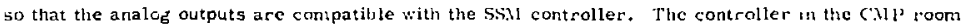
and the controller for the vault dock utilize the Anplog subsystem to monitor the rotary position of the STM carrousel as well as the sensors in the Container Modules. In the CXl' roan the weight of the CuI is determined is a linear potentiometer (coupled with a syring) that must lue conditioned by th:? Analog Subsystem. 


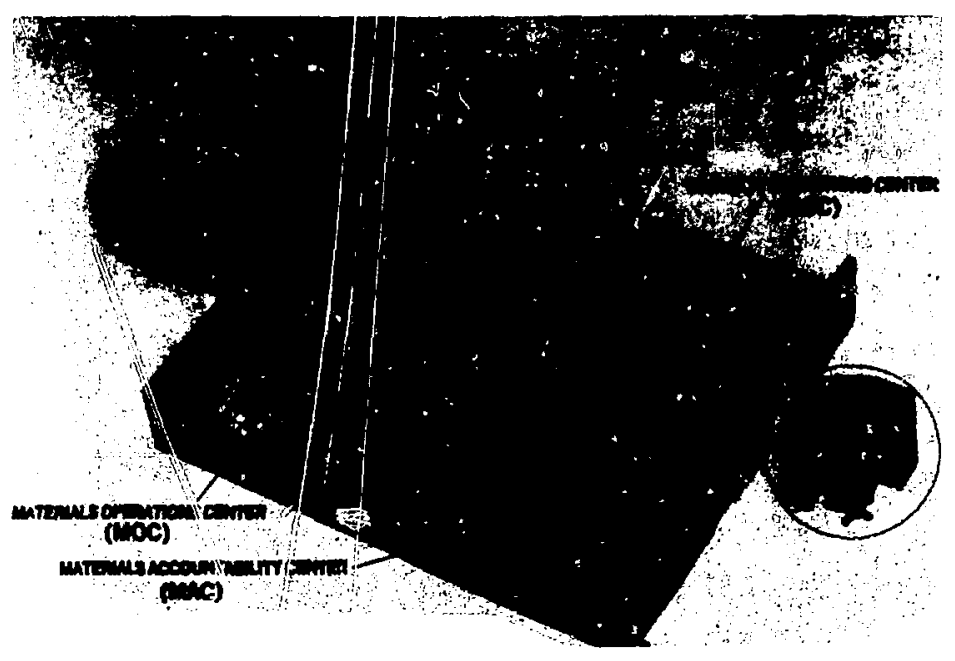

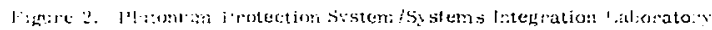

Siungin

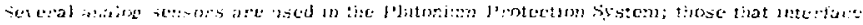

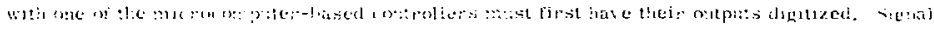

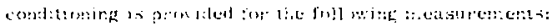

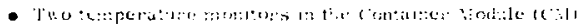

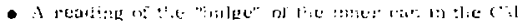

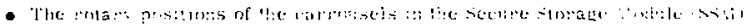

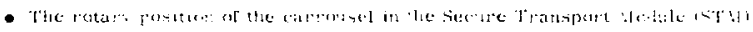

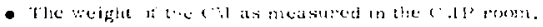

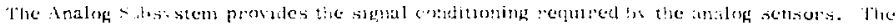

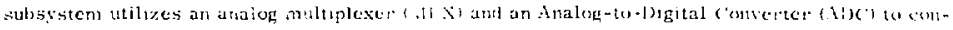

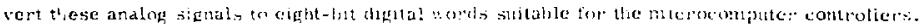


The analog inputs are divided into direct and indirect elannels. The direct channels monitor a single sensar such as the position of each rarrousel in the SSMT, the carrousel in the SI 1 , und th 2 spring-lalance in the $\left(2, L^{2}\right.$ room. These sensors are potentiometers powered $b y+5$ and -5 ;o) references, whose outputs go directly to the analog HLX. The indirect channels munitor thit sensors in each CM. Because of the large nLmber of sensors involved, a "CM selection" scheme is used which activates only the Clf of interest, even though as many as 35 monitors may he connectesl to a single input of the Analog Subsystem. The indirect channels are buffered by current summing amplifiers before going to the analog MLX.

Systers Description

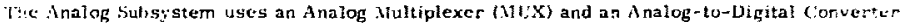
(A) () to convert anblog inputs to eight-bit digital words suitable for the microcomputer controllers ${ }^{1}$ in the F'PS. The tem AUCALX is commonly used when referring to the Analog Subsystem. This subsystem is used in three distinct applications:

- In lue SSW, aralog signals from the rotary potentiometer ${ }^{2}$ on the corrousejs. and the state-of-health moritors in the containers ${ }^{3}$ are digitized by the Auctall $\mathrm{x}$. This unit is located on the fat right-hand end of the electronics enclosure, when viewed from the front.

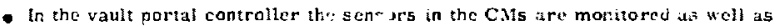
the position of the STM carrousel. ${ }^{4}$ This unit is located its the vault contro] room tr, the control!er marked 'STN Controlltr.'

- In the Call rom the same sersoms are monitorud as in the vault porta! coz-

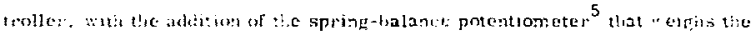

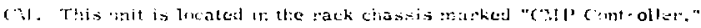

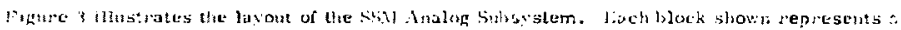

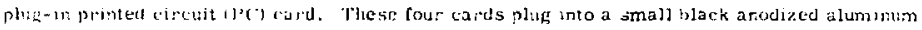

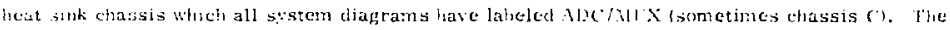

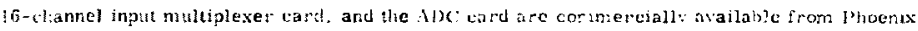
bata. and the current-tomoltage converter card and the power supply eade are mace at bandas. ippetedi i contains all pertinent schemates and lata sheets.

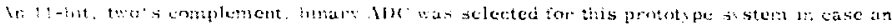

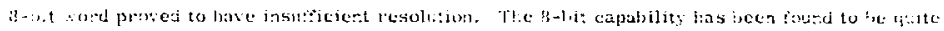

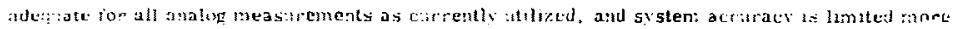
in si stem power supply woltages ond weciarical couplangs, especially in regards to carroisel iriational position. 


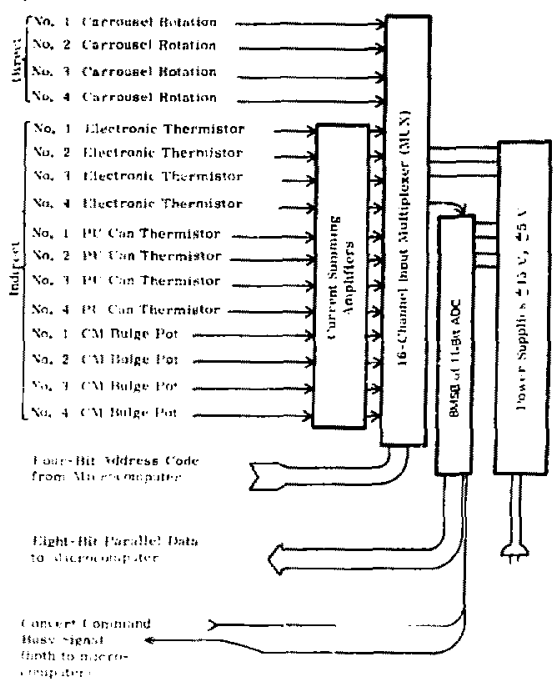

Figure $:$

Sis 3 nelok Sithititem

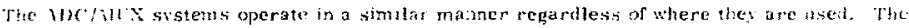

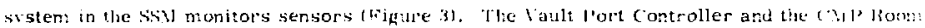

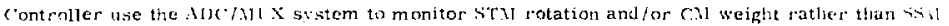

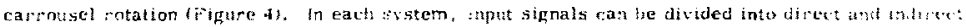
channels ifigures 3 and 4 ).

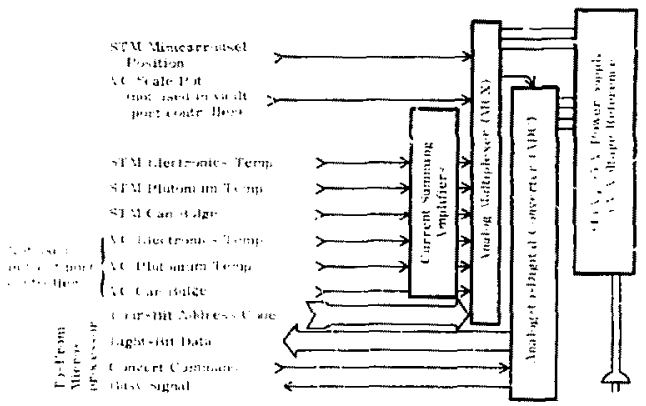

Figurc 4, vatu Port and CMí Room Anulop Suhsystem 


\section{Direct Channe?s}

Direct channels montor only a gingle sensor such as the position of each ansousel in the SSM. the carrousel in the $\$ T \lambda$, and the detector of the spring-balance weighing scale in the Verification Chamber (VO). In every case, the transducer is a potentiometer powered by -5 and -5 -volt reference voluges on the $A \cap C / M X$ power supply card. These voltages may be moritored at pin jacks on the front of the chassis.

These channels are direct because there is no signal conditioning or additisnal multiplexing between the signal source (potentiometer) and the analog Mix card in the system. The microprocessor needs only to address the proper input channel, send a convert command, and then wait for the busy line to go low before taking a reading.

\section{Indirect Channels}

The remaining channels montor temperatures (thermistors) and food-pack can bulging Ahnear potentiometer) inside the C.MS. A maltiplexing scheme is used which takes advantage of the fact that most of the electronics in each C.M are turned off until interrogated by the PIS.

Fgare 5 shows hoy the variable resistance sensors are used to faed signal current into the common suiming point of the ADC/MIX $\mathrm{X}$ inpt amplifiers.

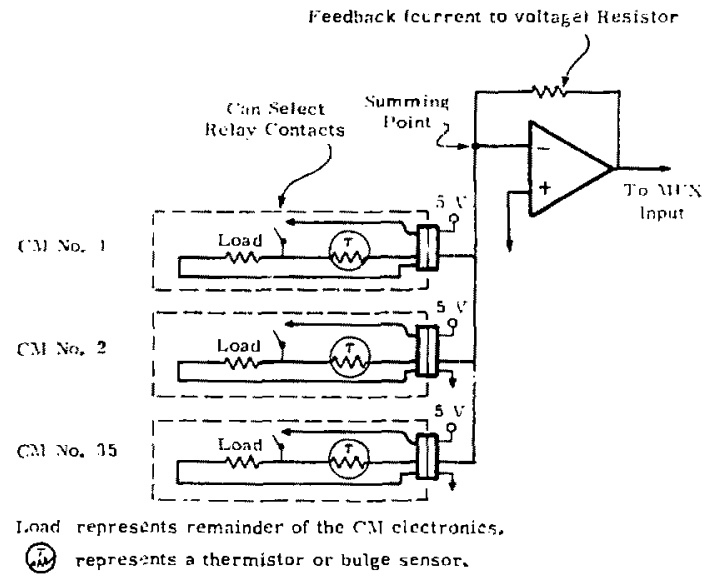

Figure 5, Var:able Resistarce Sensors 
The cancept of the acheme is aimple. When a CMt is interrogated, the relay contacts on tie selected CMI close, applying voltage to both the digital electronics and the sensor(s) inside the C11. A signal current, inversely proportional to the eeneor resistance, then flows through the carrouisel cabling to the op-amp summing junction. The op-amp outputs a voltage to the feedback rebistor so as to keep the summing polnt near zero volte. The current from the sensor is then corverted to an output valtage scross the feedback resistor.

This concept assumes that only one $\mathrm{CM}$ in each carrougel will be selected for interrogution at one tine. The other 34 CNs will be off so that the valtage acroso their sensors will be near zero and they will contribute lfttle or no current to the summing junctiol, regardless of their resistance.

Because of leakage currerts, ground loops, and millivolt drops due to power currents fluwing in common grwind returns, there will be noticeable errors generated as a result of this techniqui. llowever, the information needed does not require high prccision and these add-on analng mcasur'Lments have been included for very small per-unit costs $(-\$ 10.00)$ per C.H. The main purpose of these indirect measurements is to warn the system if:

- The electronics is hecoming hot enough to fail

- The plutonium can seal is approaching its integrity temperature

- 'lie plutorium can starts to bulge

- There is no longer any heat Mow out of the $c 21$, indicating that the rudioactuv. misteriat is gane.

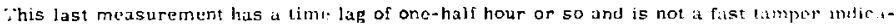
tor.

Drawing CK-T42789 in Appendix $A$ shows how the indirect measuremen:s come straight in

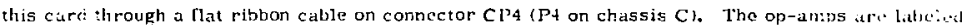
L'-1 to L'-12. The fredback and input hias resistors hate becn selected to give the desireri outprit voltage. The thermistors have a nonlinear negative temneraure cociticient; the data ure listec in Table B-1 of Appendix B. \2200-9hm resistor has been placed in series with cack tivernistor to

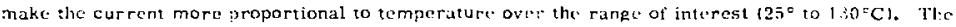
resultire voitage out is $\$ 150$ in Appendix $B$.

The feedbock resistor on each op-amp is by-passed by a capacitor to provide a low nassfitter function with a $-3 \mathrm{~dB}$ irequency of about $1000 \mathrm{~Hz}$. This filter action reduces higl: freqlicucy noise, especially clock noise from the microprocessor. A lower cutaff frequency would cause excessive settling time when a $c x t$ is selected during inventory. 
One importan g*ep Inter* nt In thls current-summing scheme to to ubsurc that the reference

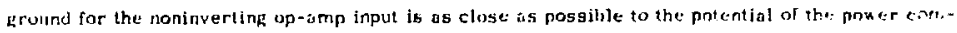

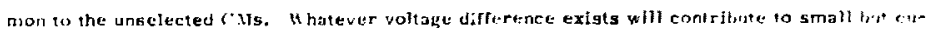
malative inputs from the sensors in those C.Ms.

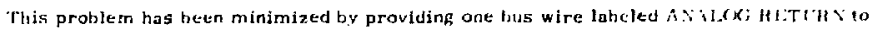
tach carrousel. "this wire carries no te power current, so il exptricncer no in drop. 13y leing

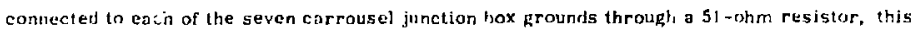

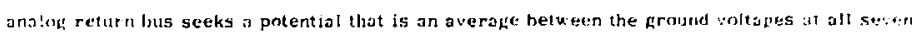

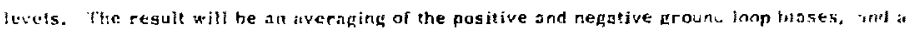

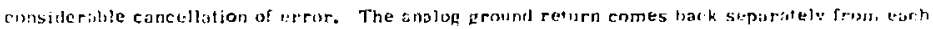

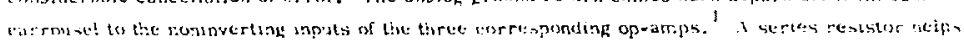

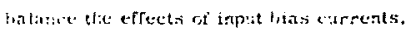

In some installations that use longer cables. such is the umbilical cable in the wallt yl ul port cuntrolter, small signols from the summing junction apparently couple over to the nrain.ering input, causing in nscillation of scyerol hundred kiloherlz. Thterdore, D. n22-microfarus bypass capacitors bave been added to the nositive inpit of each op-amp,

\section{Trantleshootine}

Th: repoir philosopty uf this chassis calls for field replecement ratler than firid repair.

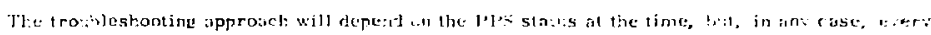

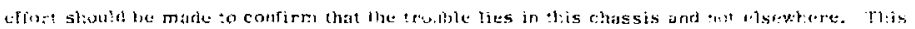

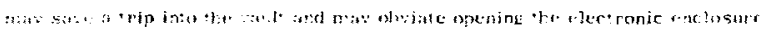

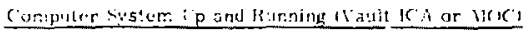

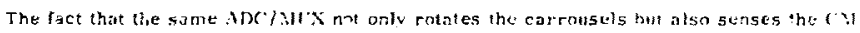
deterarc can provide is major clufs. If all ran neasurements are correct, but the rarrowsel

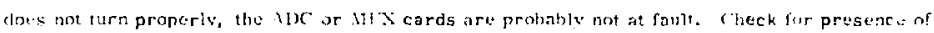
\pm 5 alts on the front of the $M D C$ MX chassis. If some carrousels turn properly hothers not,

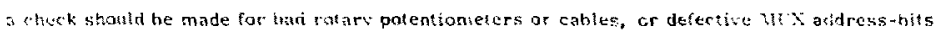
from the microprocessor. When carrousels tern well, but some or all anolog Cal channels five

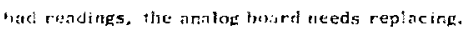

If is of the above stcps indicate that the problem ma: lie in this cliassis, and irie or radiation expostire is a protiem, the most expedient : stion is to replace the whole chassis. If conditions allow, reficine individual boards will sate time later on, but the pow supple woltages should be checked to see if they are proper before replacing other cards. 
It is important to remember that all active component g are mounted on the set of four ctaras, and it is extrenely unllkely that anv internal wlrlng will fail. To replece the boords, "ilrn iff power to the chagsis and fan. Femove fan assembly, and hat ribhon connectors and slidt llit: cards out.

\section{WARYIING:}

Cards are not keyed and if they are plugged into: $:$ e wrong slot or ingcrted upsidedown, domage will result. Figure ó illustrolus proper location and orientation.

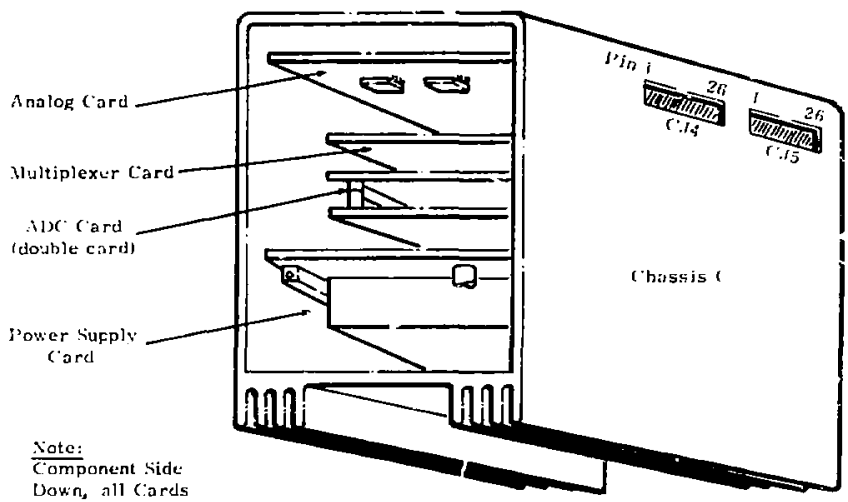

Fisfirc 6. loocation and Clrientation of l'C Cards

\section{Computers bown or Not brailable.}

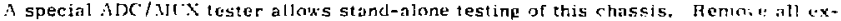
isting cables except for the pouer cord. Connect the tester cailes according in the labels. ('herh for polarity on the fat ribhon cables since they are not keved, To chuck a particular chatalel. topgle the four binary switches to get the desired VIT address as displaved or the '(-stur. I'ress

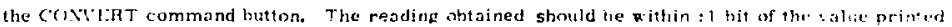

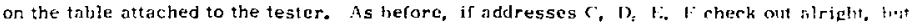
some or all of the remaining 12 channels to not, the problum lies in the analog card. 1: nowe at the channels test correctly, the problent is in the commercial cards or in the pouer s'inn!: ibe power supplv should he cheaked with a : thmeter. The 15 -voll supplies mav vart : 0.5 vil and the \pm 5 -volt jacks should each measure 4, $185 \pm 0$. 015 volts afler a 15-minute warmup. 
If the nepative 5-volt output doe日 not track the positive 5-volt supply', adjut the teimmer pot on the power oupply boa rd by removing the back cover and fan.

If any of the power supply modules are burned out, they may be replaced by removing thic two 4-40 mounting screws trom the pC board.

Replaceable parts

Yonfunctikning parts should be returned to Sandia laboratories in Albuquerque for repar: the inllowing cumponents may be replaced with spare parts:

- The entire unit may be replaced with a spare

- Vach of four individual cards may be replaced with those from the chassis in the spare unit

- The power-supply modules or the power-supply card may te replaced individually but the ge are not stocked ly Sandia.

\section{References}

1. I.estic 11. Ninnear. A ramity of Oigital Controllers for the l'lutonium protection System.

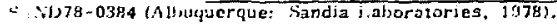

2. 1t. Wiane Arlowe. Wiring for the Secure Storage Hodule for the lalutonium l'rotection system.

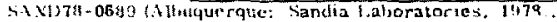

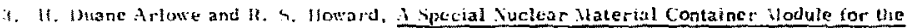

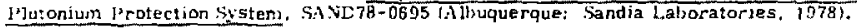

6. 11. Duane Ariowe. Wiring for the Secure I ransport lodule and lault Dock for the Plutonium

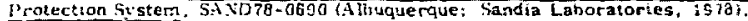

5. 11. Wuane Arlowe. Wiring for the CMl' Room and Verification Chamber for the I'lutonium

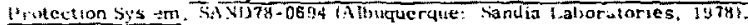


APPENDLX $\Lambda$

Schematic Diagrams 


\section{ECONOMY}

\section{ANALOG TO DIGITAL CONVERTERS}

\section{ADC 400 Series}

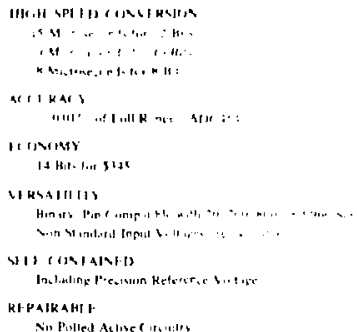

\section{GENERAL DESCRIPTION}

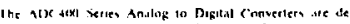

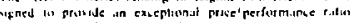

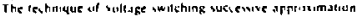

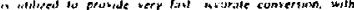

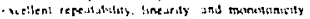

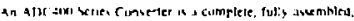

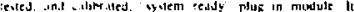

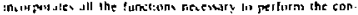

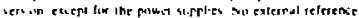

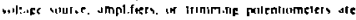
required

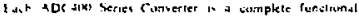

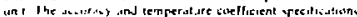

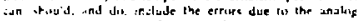

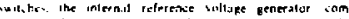

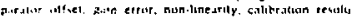

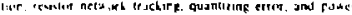

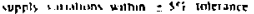

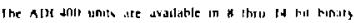

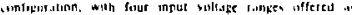

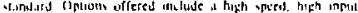

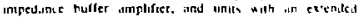
aneluing: temperature tanpe
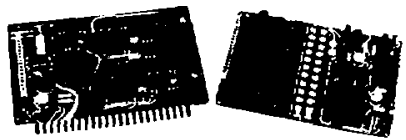

\section{OPIIONS AVAILABLE}

High Inpu: imped ince Huffer Amplifie:

I dendal (1)er at inf Temper inture R ange of aresiot In rut Vullige Romeen

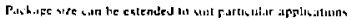

Reprinted from brochure issued by 


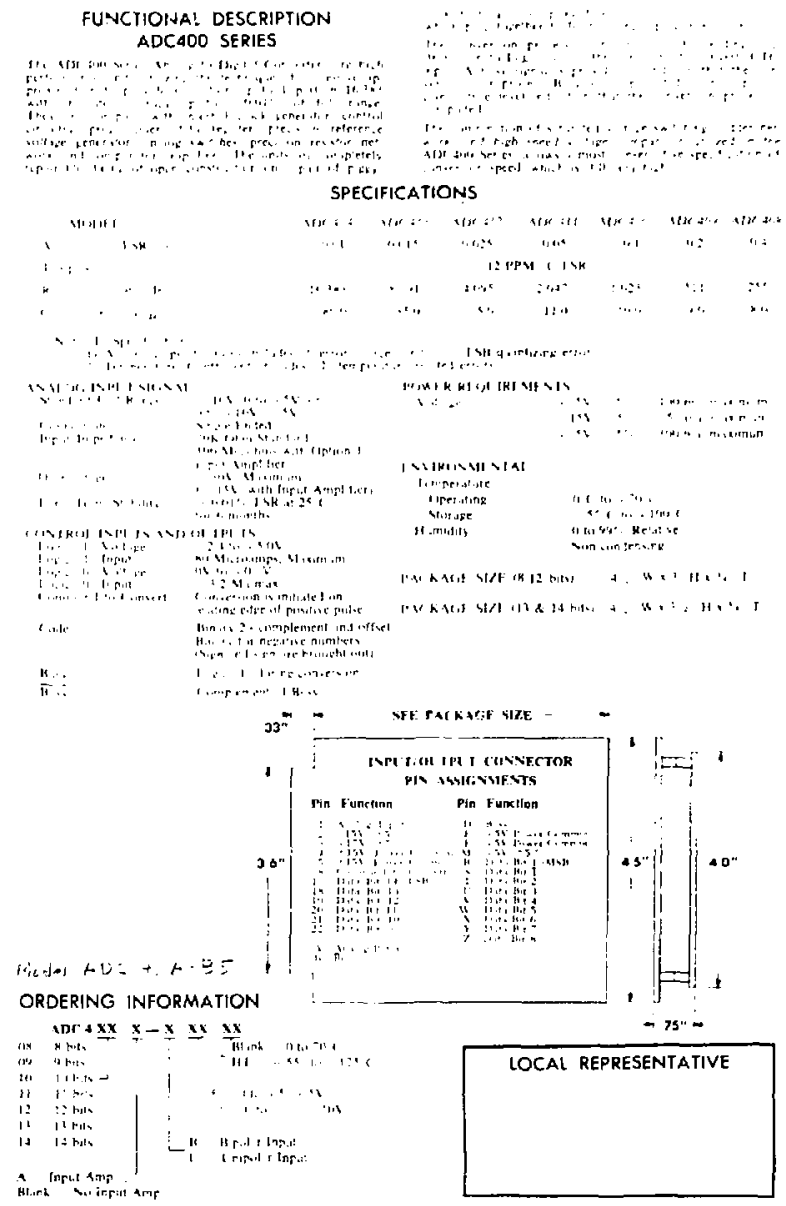





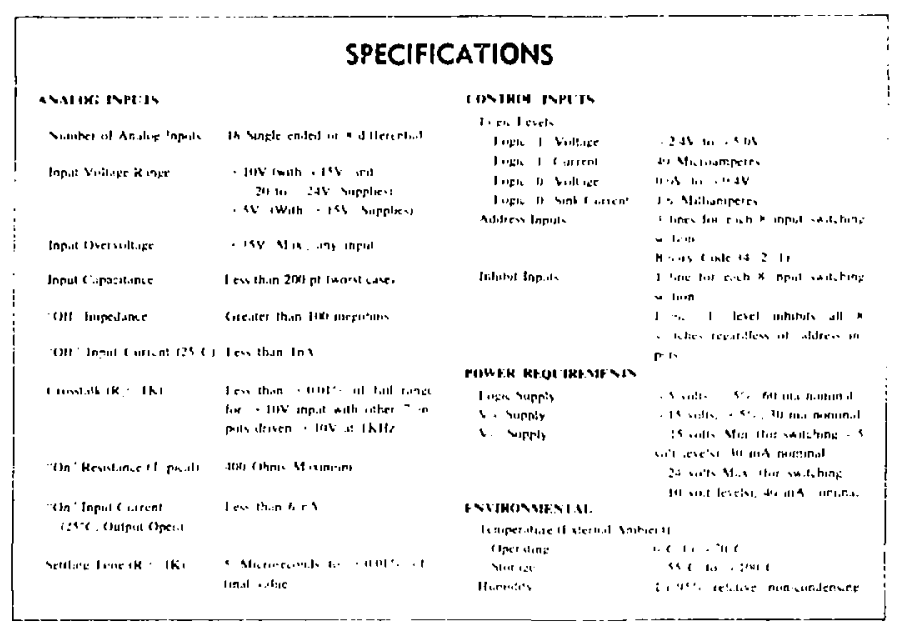

\section{APPLICATIONS}

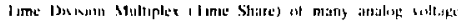

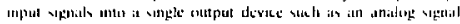

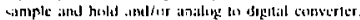

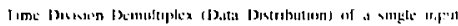

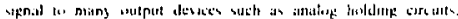

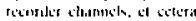

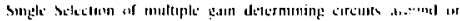

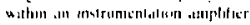

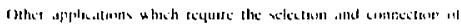

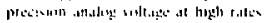

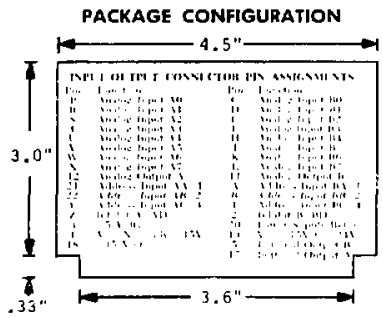

\section{OPTIONS AVAILABLE}

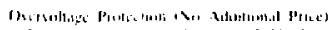

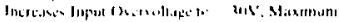

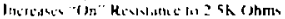

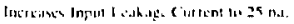

Minımim

Increise, Sittlone ! Imt

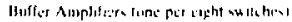

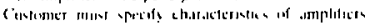

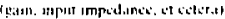

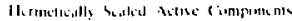

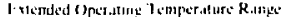

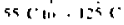

\section{LOCAL REPRESENTATIVE}


SPECIFICATIONS

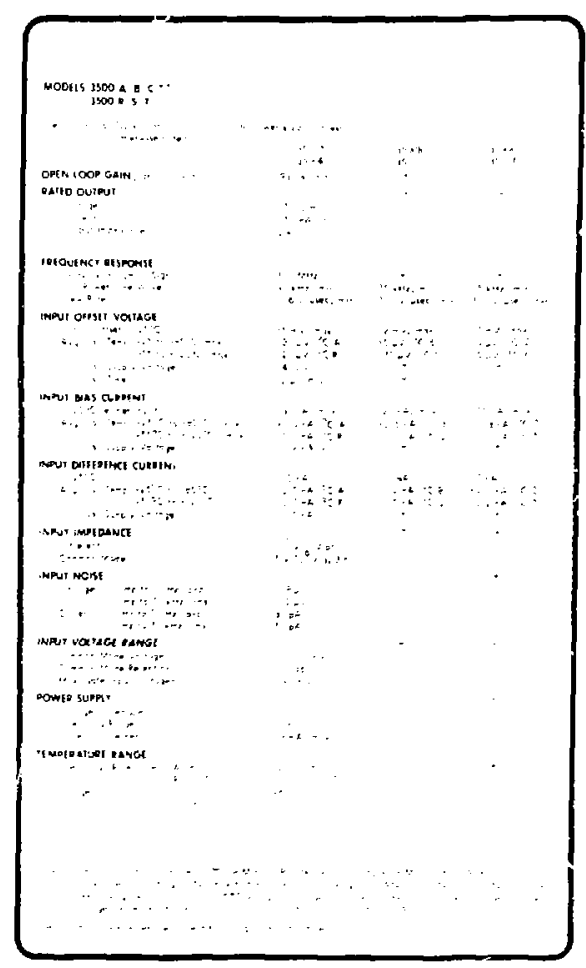

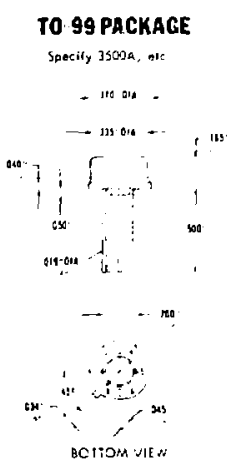

\section{MINI-DIP PACKAGE}

Sorify 35GR-kN, ore

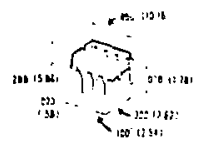

TCP AIE

Dimple eceeors over . in speces"

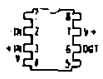

vare Dimersion ir wi reers are shour in norer'aces.

PIN CONNECTIONS

\begin{tabular}{|c|c|}
\hline MNU:L & 5) 5212 \\
\hline$F|-| \mathrm{N}$ & BCLIPUT \\
\hline $31 \cdot 1 \mathrm{~N}$ & $71 \%$ \\
\hline $41.5-$ & E.A.C. \\
\hline
\end{tabular}




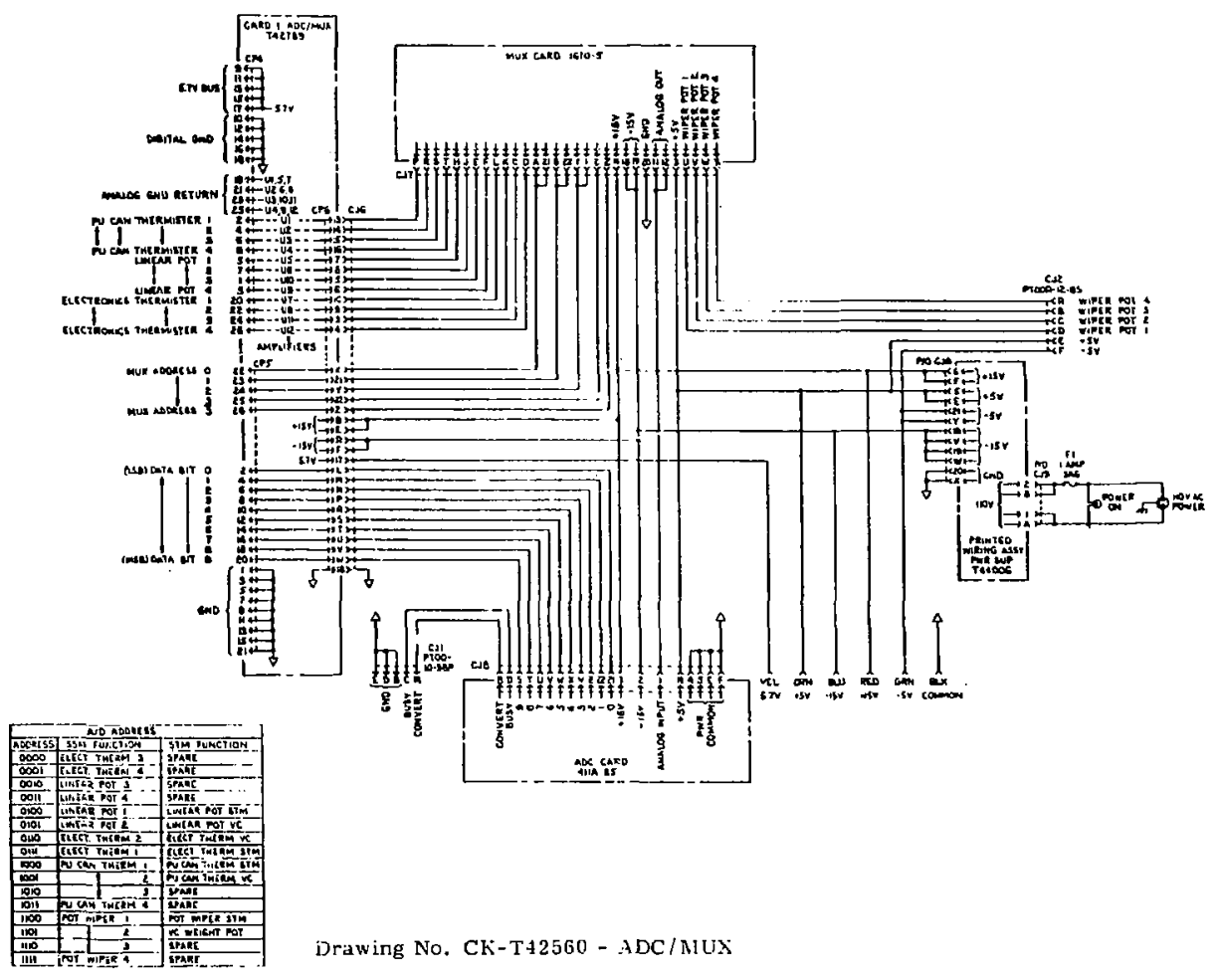




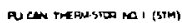

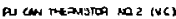

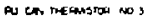

a) Con nementes wo

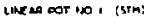

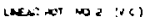

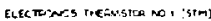

RYILO SND RE ILAM

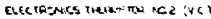

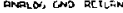

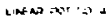

LNEA DOT No 3

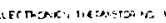
AMP-DS Gis RE: Wurt

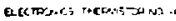
Nhai .Notrit

$9.7 \times R$.

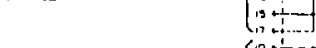

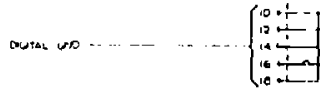

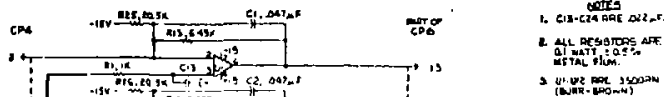

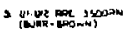

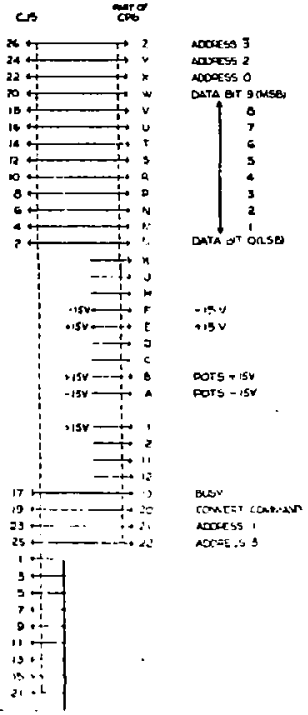

Drawing No, CK-T42789 - Analog Card, ADC/』l: 


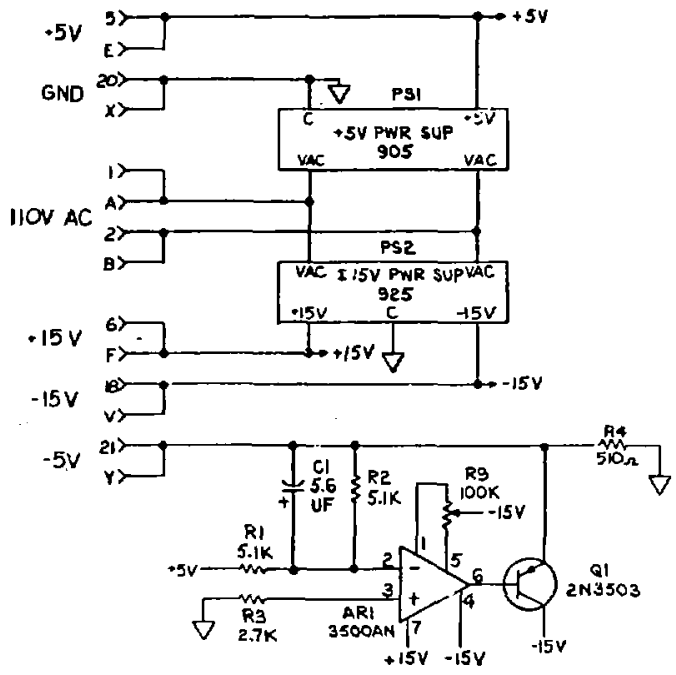

Drawing No. CK-T44006 - Power Supply 
APPENDD B

Eunersion Tables 
APPENDIX B

Conversion Tables

The analog eubsyatem components have been designed to yield the following digital output ror the temperature valueg shown. These values heve been confirmed experimentally when there is 5. B volts applied to the power connections to the Container Module.

TABLE B-1

Temperature Conversion

\begin{tabular}{|c|c|c|c|c|c|c|c|}
\hline ijecimal & $P_{T} / R_{25}$ & Temp $\left\{{ }^{\circ} \mathrm{C}\right\}$ & Hex & Decimal & $\mathrm{R}_{\mathrm{T}}{ }^{\prime l R_{25}}$ & $T=\operatorname{lomp} l^{\circ}()^{\circ}$ & 116 \\
\hline-128 & 0.0 .39 & 120 & 80 & -104 & 0.049 & 111 & 58 \\
\hline-127 & 0.038 & 120 & $\theta I$ & -103 & 0.050 & 110 & $y$ \\
\hline-126 & $0.03 \mathrm{~B}$ & $1: 0$ & A2 & -102 & 0. 050 & 110 & 3 \\
\hline-125 & 0.039 & 119 & B3 & -101 & 0.031 & 110 & 213 \\
\hline-124 & 0.039 & 113 & 84 & -100 & 0.052 & $\operatorname{lon}$ & $1 \mathrm{C}:$ \\
\hline-123 & 0.040 & 119 & 35 & -93 & 0. 032 & 109 & $\eta \Gamma$ \\
\hline-122 & D. 040 & 119 & 86 & $-9 B$ & 0.053 & 100 & "1. \\
\hline-121 & 0.041 & 118 & 87 & -97 & 0.053 & $10 !$ & $4 \mathrm{~F}$ \\
\hline-120 & 0. 041 & 118 & 88 & -96 & 0.054 & 108 & 10 \\
\hline-119 & 0. บิ42 & 117 & 89 & -95 & D. 0.54 & $\ln B$ & $M$ \\
\hline-118 & 0,042 & 117 & $8 n$ & -14 & 0.055 & 107 & .12 \\
\hline-117 & $\vec{t}, 043$ & 115 & $8 R$ & -93 & 0.056 & 107 & 13 \\
\hline-116 & 0.043 & 116 & $8 C$ & -92 & 0.055 & 107 & $\therefore 4$ \\
\hline-115 & 0.044 & 115 & 8D & -91 & 0.057 & 106 & 15 \\
\hline-114 & 0.044 & 115 & $8 E$ & -90 & 0.057 & 106 & $\therefore r$ \\
\hline-113 & 0.045 & 119 & $8 F$ & -89 & 0.058 & 105 & $\$ 7$ \\
\hline-112 & 0.045 & 114 & 90 & -88 & 0.050 & $: 04$ & A \\
\hline-111 & 0.046 & 114 & n & -87 & $0.05 !$ & $: 04$ & .99 \\
\hline-110 & 0.046 & 114 & $\mathbf{9 2}$ & -86 & $0.0 \operatorname{sis} 0$ & 104 & $1:$ \\
\hline-100 & 0.047 & 113 & 93 & -85 & $0,0 \in 1$ & 104 & $A B$ \\
\hline-108 & 0.047 & 113 & 94 & -84 & 0.061 & $: 04$ & $\therefore C$ \\
\hline-107 & 0,048 & 112 & 95 & -83 & 0.062 & 103 & $A n$ \\
\hline-106 & 0.048 & 112 & 96 & -82 & 0.063 & 103 & $A E$ \\
\hline-105 & 0.049 & 111 & 99 & -81 & 0.063 & 10.3 & $\therefore F$ \\
\hline
\end{tabular}


TABLE B-I (cont)

\begin{tabular}{|c|c|c|c|c|c|c|c|}
\hline Decimal & $\mathrm{R}_{\mathrm{T}} / \mathrm{R}_{25}$ & Temp $\left({ }^{\circ} \mathrm{C}\right)$ & Hex & Decimal & $\mathrm{R}_{\mathrm{T}} / \mathrm{R}_{25}$ & Temp $\left({ }^{\circ} \mathrm{C}\right)$ & Hex \\
\hline-80 & 0.064 & 192 & $\mathbf{B O}$ & -43 & 0.095 & 89 & D5 \\
\hline-79 & 0.065 & 101 & B1 & -42 & 0.096 & 88 & D6 \\
\hline-78 & 0,065 & 101 & $\mathbf{B 2}$ & -41 & 0.097 & 88 & D7 \\
\hline-77 & 0.066 & 101 & B3 & -40 & 0.098 & 88 & DP \\
\hline-76 & 0.067 & 100 & B4 & -39 & 0.099 & 87 & T19 \\
\hline-75 & 0.067 & 100 & B5 & -38 & 0.100 & 87 & $D A$ \\
\hline-74 & 0.068 & 100 & B6 & -37 & 0.101 & 87 & DB \\
\hline-73 & 0.069 & 99 & B? & -36 & 0.102 & 86 & or \\
\hline-72 & 0.070 & 29 & $\mathrm{BP}$ & -35 & 0.103 & 86 & DD \\
\hline$-7 !$ & 0.070 & 90 & $\mathrm{Bg}$ & -34 & $0.10 \mathrm{a}$ & 86 & $D E$ \\
\hline-70 & 0.071 & 98 & $\mathrm{BA}$ & -33 & 0.106 & 85 & $\mathrm{DF}$ \\
\hline-69 & 0.072 & 98 & $\mathrm{BB}$ & -32 & 0.107 & 85 & EO \\
\hline-68 & 0.072 & 97 & $B C$ & -31 & 0.108 & 85 & $\mathrm{E} 1$ \\
\hline-67 & 0.073 & 97 & $\mathrm{BD}$ & -30 & ก. 109 & 84 & E2 \\
\hline-66 & 0.074 & 97 & $\mathrm{BE}$ & -29 & 0.110 & 84 & 63 \\
\hline-65 & 0.075 & 96 & $B F$ & -28 & 0.112 & 84 & $\mathbb{E 4}$ \\
\hline-64 & 0.076 & 96 & Co & -27 & 0.113 & 83 & E5 \\
\hline-63 & 0.077 & 96 & $\mathrm{Cl}$ & -26 & 0.114 & 83 & $\$ 6$ \\
\hline-62 & 0.077 & 96 & $\mathrm{C2}$ & -25 & 0.115 & 83 & $\mathrm{E7}$ \\
\hline-61 & 0.078 & 95 & $\mathrm{CB}$ & -24 & 0.117 & 82 & 18 \\
\hline-60 & 0.079 & 95 & $c 4$ & -23 & 0.118 & 82 & $\mathrm{Eg}$ \\
\hline$-5 n$ & 0.080 & 94 & $\mathrm{C5}$ & -22 & 0.119 & $B 2$ & $\because n$ \\
\hline-58 & 0.081 & 94 & C. & -23 & 0.121 & 8) & EB \\
\hline-57 & 0.082 & 94 & $\mathrm{C7}$ & -20 & 0.122 & 81 & $E C$ \\
\hline-56 & o. 082 & 94 & $\mathrm{CB}$ & -19 & D. 124 & 80 & ED \\
\hline-55 & 0.083 & 83 & $\mathrm{cos}$ & -16 & 0.125 & 80 & $\mathrm{EF}$ : \\
\hline-54 & o. 084 & 93 & $\mathrm{CA}$ & -17 & 0.126 & 80 & $\mathrm{EF}$ \\
\hline-53 & 0.085 & 32 & $C B$ & -16 & 0.128 & 79 & Fo \\
\hline-52 & o. 086 & 92 & $\mathrm{cC}$ & -15 & 0.129 & 79 & $\mathbf{F I}$ \\
\hline-51 & 0.087 & 92 & $\mathrm{cD}$ & -14 & 0.131 & 79 & $\mathbf{F 2}$ \\
\hline-50 & 0.088 & 91 & Cl: & -13 & 0.132 & 78 & $1 \% 3$ \\
\hline-49 & 0. 089 & $n 1$ & $C F$ & -12 & 0. 134 & 78 & $F q$ \\
\hline-48 & 0.090 & 90 & Do & -11 & 0. 135 & $7 B$ & F5 \\
\hline-47 & 0.091 & 90 & $\mathrm{D} 1$ & -10 & 0.137 & 77 & $F 6$ \\
\hline-46 & 0.092 & 90 & $\mathrm{D} 2$ & -9 & 0.139 & 77 & $F 7$ \\
\hline-45 & 0.093 & 89 & D3 & -8 & 0.140 & 77 & F8 \\
\hline-44 & 0.094 & 89 & $\mathrm{D} 4$ & & & & \\
\hline
\end{tabular}


TABLE B-1 (cont)

\begin{tabular}{|c|c|c|c|c|c|c|c|}
\hline Decimal & $\mathrm{R}_{\mathrm{T}} / \mathrm{H}_{25}$ & Temp $\left({ }^{\circ} \mathrm{C}\right)$ & Hex & Decimal & $\mathrm{R}_{-\mathrm{T}} / \mathrm{R}_{25}$ & Temp (U) & Hey \\
\hline-7 & 0.142 & 76 & $\mathrm{Fg}$ & 30 & 0.2 .29 & 62 & $1 \%$ \\
\hline-6 & 0.144 & 76 & $\mathrm{FA}$ & 31 & 0.232 & 62 & $1 F$ \\
\hline-5 & 0.145 & 75 & FB & 32 & 0.236 & 61 & 20 \\
\hline-4 & 0.147 & 75 & FC & 33 & 0.239 & 01 & 21 \\
\hline-3 & 0.149 & 75 & FD & 34 & 0.243 & 61 & 22 \\
\hline-2 & 0.151 & 74 & FE & 35 & 0.246 & 60 & 23 \\
\hline-1 & 0.152 & 74 & $F F$ & 36 & 0.250 & 60 & 24 \\
\hline 0 & 0.154 & 74 & 00 & 37 & 0.254 & $5 ?$ & $\mathbf{2} 5$ \\
\hline 1 & 0.156 & 73 & 01 & 38 & 0.258 & $5 ?$ & 26 \\
\hline 2 & 0.158 & 73 & 02 & 39 & 0.262 & 59 & 27 \\
\hline 3 & 0.160 & 73 & 03 & 40 & 0.266 & 58 & 28 \\
\hline 4 & 0.162 & 72 & 04 & 41 & 0.270 & 58 & 29 \\
\hline 5 & 0.164 & 72 & 05 & 42 & 0.275 & 57 & $2 A$ \\
\hline 6 & 0.166 & 71 & 06 & 43 & 0.279 & 57 & $2 B$ \\
\hline 7 & 0.168 & 71 & 07 & 44 & 0.284 & 56 & $2 C$ \\
\hline 8 & 0.170 & 71 & 08 & 45 & 0.238 & 56 & $2 D$ \\
\hline 9 & 0.173 & 70 & 09 & 46 & 0.293 & 55 & $2 E$ \\
\hline 10 & 0.175 & 70 & $O A$ & 47 & 0.298 & 55 & $2 F$ \\
\hline 11 & 0.177 & 70 & $0 \mathrm{~B}$ & 48 & 0.303 & 55 & 30 \\
\hline 12 & 0.179 & 69 & $\mathrm{OC}$ & 49 & 0.308 & 54 & 31 \\
\hline 13 & 0.182 & 69 & $O D$ & 50 & 0.314 & 54 & 32 \\
\hline 14 & 0.184 & 68 & $O E$ & 51 & 0.319 & 53 & 33 \\
\hline 15 & 0.186 & 68 & $O F$ & 52 & 0.325 & 53 & 34 \\
\hline 16 & 0.189 & 68 & 10 & 53 & 0.331 & 52 & 35 \\
\hline 17 & 0.191 & 67 & 11 & 54 & 0.337 & 52 & 36 \\
\hline 18 & 0.194 & 67 & 12 & 55 & 0.343 & 51 & 37 \\
\hline 19 & 0.137 & 67 & 13 & 56 & $0.34 !$ & 51 & 38 \\
\hline 20 & 0.139 & 66 & 14 & 57 & 0.356 & 50 & $3 ?$ \\
\hline 21 & 0.202 & 66 & 15 & 58 & 0.362 & 50 & $3 A$ \\
\hline 22 & 0.205 & 65 & 16 & 59 & 0.36 ? & $4 !$ & $3 B$ \\
\hline 23 & 0.208 & 65 & 17 & 60 & 0.375 & $4 !$ & $3 C$ \\
\hline 24 & 0.210 & 65 & 18 & 61 & 0. 384 & 48 & $3 \mathrm{D}$ \\
\hline 25 & 0.213 & 64 & 19 & 62 & 0.392 & 48 & $31:$ \\
\hline 26 & 0.216 & 64 & $1 \mathrm{~A}$ & 63 & 0.400 & 47 & $31:$ \\
\hline 27 & 0.219 & 64 & $1 B$ & 64 & 0.408 & 47 & 40 \\
\hline 28 & 0.223 & 63 & $1 C$ & 65 & 0.416 & 46 & 41 \\
\hline 29 & 0.226 & 63 & $1 \mathrm{D}$ & 66 & 0.425 & 46 & 42 \\
\hline
\end{tabular}


ТАВі: B-1 (cont)

\begin{tabular}{|c|c|c|c|}
\hline Decimn & $\mathrm{R}_{\mathrm{T}} / \mathrm{R}_{25}$ & Temp ( ${ }^{\circ}(:)$ & IIex \\
\hline 67 & 0.434 & 45 & 4.9 \\
\hline 68 & 0.444 & 44 & 44 \\
\hline 69 & 0.454 & 44 & 45 \\
\hline 70 & 0.464 & 43 & 46 \\
\hline 71 & 0.475 & 43 & 47 \\
\hline 72 & 0.486 & 42 & 48 \\
\hline 73 & 0.497 & 12 & $4 !$ \\
\hline$i 4$ & 0.509 & 41 & $4 \lambda$ \\
\hline$\pi 5$ & 0.522 & 40 & 413 \\
\hline 76 & 0.535 & 40 & 4r: \\
\hline 77 & $0.54 !$ & 39 & $45)$ \\
\hline 78 & 0.56 .3 & $3 ! !$ & $4:$ \\
\hline 79 & 0.578 & $3 B$ & $4 \%$ \\
\hline 80 & $0.5 ! 14$ & 37 & 50 \\
\hline BI & 0,610 & 37 & 51 \\
\hline 82 & 0.627 & 36 & 52 \\
\hline 4.3 & 0.946 & .75 & 53 \\
\hline 34 & 0.665 & 94 & 54 \\
\hline 85 & 0.685 & 34 & 55 \\
\hline BO & 0,707 & 33 & 56 \\
\hline B7 & 0.729 & 32 & 57 \\
\hline 88 & 0.753 & 32 & 58 \\
\hline $3 . ?$ & 0.779 & .31 & $5 !$ \\
\hline 9 & 0.806 & $3 \pi$ & $5:$ \\
\hline 01 & 0.835 & 29 & $5 B$ \\
\hline 92 & 0.865 & $2 B$ & $5 \mathrm{C}$ \\
\hline 93 & 0.898 & 27 & $5 D$ \\
\hline 24 & 0.934 & 27 & $5 E$ \\
\hline .25 & 0.972 & 26 & $5 \mathrm{I}$ \\
\hline 96 & 1.013 & 25 & 60 \\
\hline 97 & 1.057 & 24 & fil \\
\hline 98 & 1.106 & 23 & 62 \\
\hline 99 & 1.158 & 22 & 63 \\
\hline 100 & 1.215 & 21 & 64 \\
\hline 101 & 1.278 & 19 & $=7$ \\
\hline 102 & 1.348 & 18 & 66 \\
\hline 103 & 1.425 & 17 & 67 \\
\hline
\end{tabular}

\begin{tabular}{ccccc} 
Decimal & & $R_{T} / R_{25}$ & Temp $\left.{ }^{\circ} \mathrm{C}\right)$ & Hex \\
\cline { 1 - 1 } 104 & & 1.511 & 16 & $6 \mathrm{H}$ \\
105 & 1.607 & 14 & 69 \\
106 & 1.716 & 1.3 & $6 \mathrm{~A}$ \\
107 & 1.840 & 12 & $6 \mathrm{~B}$ \\
108 & 1.982 & 10 & $6 \mathrm{C}$ \\
109 & 2.147 & 8 & $6 \mathrm{D}$ \\
110 & 2.341 & 7 & 65 \\
111 & 2.572 & 5 & $6 F$ \\
112 & 2.851 & 3 & 70 \\
113 & 3.197 & 0 & 71 \\
114 & 3.6 .36 & & 72
\end{tabular}


TABLE B-2

Bulge Sensor Conversion

\begin{tabular}{|c|c|c|c|c|}
\hline $\begin{array}{c}\text { Upper } \\
\text { Deflection } \\
\end{array}$ & $\begin{array}{l}\mathrm{I}_{\text {in }} \\
\mathrm{L}_{\text {in }} \cdot \mathrm{Pot} \\
\text { Wiper } \\
\text { (volts) } \\
\end{array}$ & $\begin{array}{c}E_{o} \\
\text { Amplifler } \\
\text { Output } \\
\text { (volts) } \\
\end{array}$ & Decimal & llex (Al) \\
\hline $0-1 \mathrm{~mm}$ & 0.00 & 4. 96 & 127 & $7 \%$ \\
\hline 2 & 0.38 & 4. 18 & 107 & $6 B$ \\
\hline 3 & 0.76 & 3.40 & 87 & 57 \\
\hline 4 & 3.14 & 2.62 & 67 & 43 \\
\hline 5 & 1.52 & 1.84 & 47 & 21 \\
\hline$E$ & 1.90 & 1.06 & 27 & in \\
\hline 7 & 2.28 & 0.286 & 7 & 07 \\
\hline B & 2,66 & -0.49 & -12 & $\mathrm{~F} 4$ \\
\hline 9 & 3,04 & -1.27 & -32 & ED \\
\hline 10 & 3.92 & -2.05 & -52 & $\mathrm{cc}$ \\
\hline 11 & 3.81 & -2.85 & -73 & I37 \\
\hline 11.5 & 4. 00 & -3.24 & -83 & $A D$ \\
\hline
\end{tabular}

ТА乃1: $3-3$

Verification Chamber Scale

$\left(\mathrm{wt}_{\mathrm{kg}}=\frac{\text { reoding }_{\text {Dec }}-18}{\mathrm{i3}}\right)$

\begin{tabular}{lcc}
$\begin{array}{c}\text { Scale Tare } \\
\text { (wt kg) }\end{array}$ & Jecirral & Jex \\
\cline { 2 - 3 } 0 & -4 & $\mathrm{FC}$ \\
0.5 & 14 & $\mathrm{OE}$ \\
1.0 & 20 & 14 \\
1.5 & 27 & $1 \mathrm{~B}$ \\
2.0 & 34 & 22 \\
2.5 & 40 & 28 \\
3.0 & 46 & $2 \mathrm{E}$ \\
& 53 & 35
\end{tabular}


TAMA: B-4

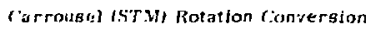

\begin{tabular}{|c|c|c|c|c|}
\hline $\begin{array}{c}\operatorname{srm} \\
\text { Jostion } \\
\end{array}$ & $\begin{array}{c}\text { ssin } \\
\text { position } \\
\end{array}$ & $\begin{array}{c}\text { "ot Wiper } \\
\text { (valts) } \\
\end{array}$ & JJer.jmal & Ifex \\
\hline \multirow[t]{2}{*}{ linds } & lind & -5.00 & -128 & 80 \\
\hline & 1 & -4.98 & -125 & 83 \\
\hline \multirow[t]{2}{*}{1} & 2 & -4.35 & -112 & 0 \\
\hline & 3 & -3.85 & צ'נן & 7i) \\
\hline \multirow[t]{2}{*}{ Null } & 4 & -3.33 & -85 & $\mathrm{AH}$ \\
\hline & 5 & -2.82 & -72 & THB \\
\hline \multirow[t]{2}{*}{2} & ; & -2.30 & -54 & $C 5$ \\
\hline & I & -1.78 & $-4 i$ & i)2 \\
\hline \multirow[t]{2}{*}{$N_{1111}$} & 13 & -1.27 & -3.3 & ij \\
\hline & 9 & -0.75 & -19 & (E) \\
\hline \multirow[t]{3}{*}{3} & 10 & -0.24 & $-6)$ & $1 \% A$ \\
\hline & $N_{11} 11$ & 0.02 & 0 & 00 \\
\hline & 11 & 0.28 & 7 & 07 \\
\hline \multirow[t]{2}{*}{ Ninll } & 12 & 0.74 & 20 & 14 \\
\hline & 1.3 & 1.31 & 3.3 & 21 \\
\hline \multirow[t]{2}{*}{4} & 14 & 1. H2 & 47 & $2 \mathrm{l}:$ \\
\hline & 15 & 2.34 & r.o & $3 c$ \\
\hline \multirow[t]{2}{*}{ silll } & 16 & 2. 85 & 73 & $4 !$ \\
\hline & 17 & 3.37 & M; & $5 f$ \\
\hline \multirow[t]{3}{*}{5} & 13 & 3. ни & 98 & 62 \\
\hline & 19 & 4.40 & 113 & 71 \\
\hline & 20 & 4. 11 & 126 & 71: \\
\hline lind & lined & 5.00 & 127 & 71 \\
\hline
\end{tabular}


TABLI: $\Pi-5$

Resigtance - Temperatire Conversion

The following irformation may he used to test or callbrate the temperature channels in the SSM, STM, or Verification Chamber. The reslstance values represent precigion registors commonly available at Sand: 4 and correctly simulate the thermistor resigtance plus 2200 ohms wher 5.0 volts to applied to one side of the resistor and the other end of the resigtor is connected to pin I: (electronics tempurature) or pin $Y$ (plutonium thermistor).

The current column is the resulting current that flows into the AIJC/MIX amplifiter su.uning junction when the simulator resistor is uged with 5.0 volts fmpressed.

\begin{tabular}{|c|c|c|c|c|}
\hline $\begin{array}{l}\text { for } \\
\text { femp }\end{array}$ & $\begin{array}{c}R_{\text {in }} \\
\text { (k ohms) }\end{array}$ & $\begin{array}{l}\text { Nmplifier } \\
\mathrm{I}_{\text {in }}(\mathrm{m})\end{array}$ & $\because \mathrm{o}$ & Hex \\
\hline $12 r_{1}$ & 3.48 & 1.43 & -4.53 & $89-8 A$ \\
\hline 100 & 4.22 & 1.18 & -2.9 & $\mathrm{~B}+\mathrm{A}-\mathrm{BS}$ \\
\hline 86 & 5.36 & 0.932 & -1.3 & DE: \\
\hline in & 7.50 & 0.666 & 0.42 & $O A-O B$ \\
\hline 50 & 12.7 & $0.3 \leqslant 3$ & 2.20 & 39 \\
\hline $2 !$ & 27.4 & 0.182 & 3.56 & $5 B$ \\
\hline$\because \mathrm{C}^{\circ}$ & & 0 & 4. 75 & 79 \\
\hline
\end{tabular}

letrecolit 
12151 $110+4$ i $16: \cdots$

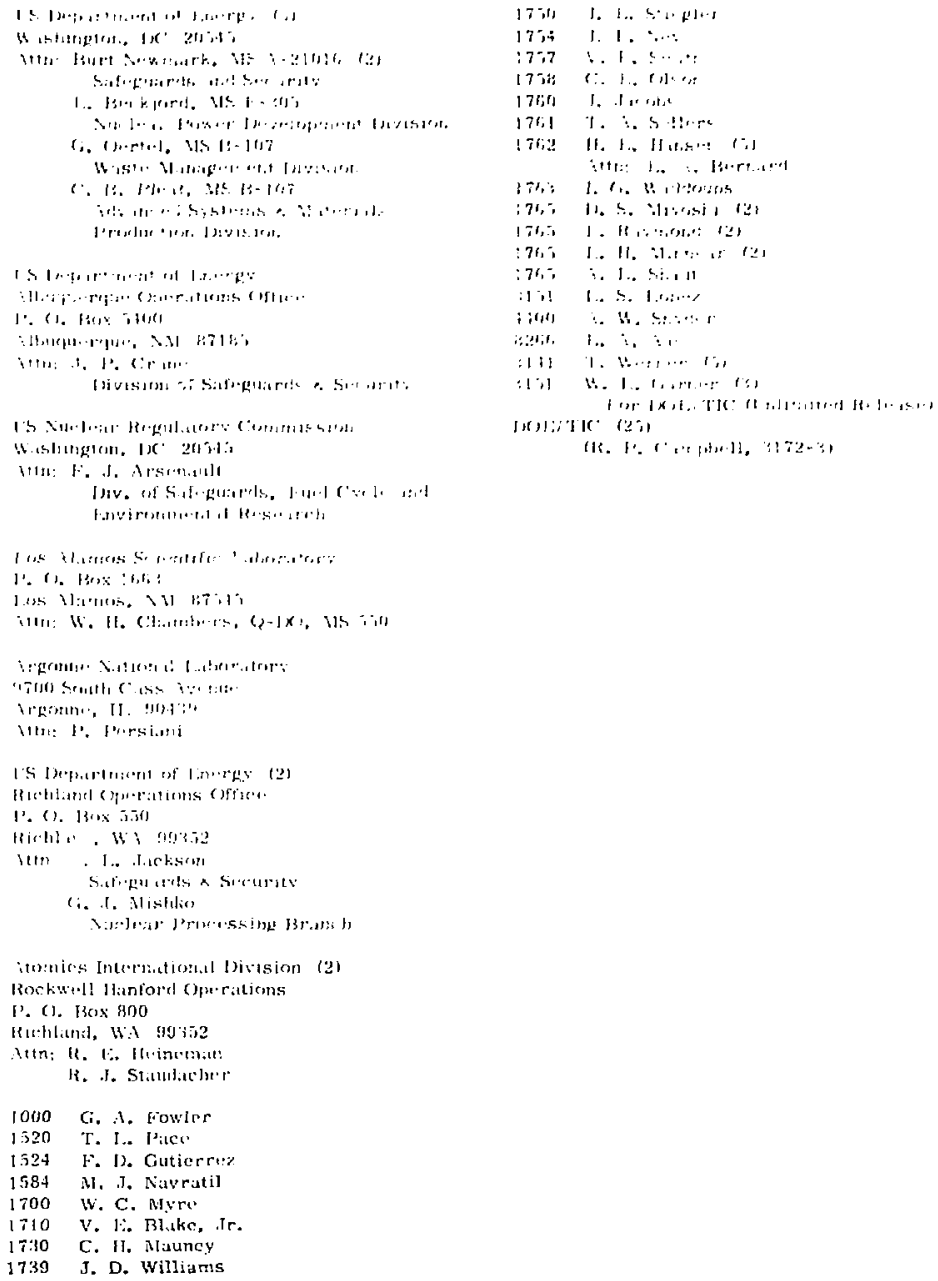

